\title{
Chediak-Higashi Syndrome - A Report of Two Cases with Unusual Hyperpigmentation of the Face
}

\author{
Chediak-Higashi Sendromu - Sıradışı Yüz Hiperpigmentasyonu ile \\ Kendini Gösteren İki Olgu
}

\author{
Mukta PUJANI, Kiran AGARWAL, Shashi BANSAL, Israr AHMAD, Vandana PURI, Deepti VERMA, \\ Meenu PUJANI
}

Department of Pathology, Lady Hardinge Medical College, NEW DELHI, INDIA

\begin{abstract}
Chediak-Higashi syndrome is a rare autosomal recessive disorder due to a qualitative defect in leucocyte function characterized clinically by partial oculocutaneous albinism, recurrent bacterial infections, photophobia etc. The diagnostic feature is the presence of abnormal giant intracytoplasmic granules in neutrophils and their precursors. Here we report this syndrome in two siblings who presented with an unusual hyperpigmentation of the face and extremities.
\end{abstract}

Key Words: Chediak-Higashi syndrome, Albinism

\section{ÖZ}

Chediak-Higashi sendromu, otozomal resesif geçiş gösteren, kısmi okülokutanöz albinism, tekrarlayan bakteriyel enfeksiyonlar, fotofobi vb klinik bulgularla karakterize, lökosit fonksiyonunda niteliksel kusura bağlı nadir bir hastalıktır. Nötrofiller ve öncü hücrelerinde dev intrasitoplazmik granüller tanısal bulgusudur. Burada, sıradışı olarak yüz ve ekstremitelerinde hiperpigmentasyon ile kendini gösteren iki kardeşte gözlenen Chediak-Higashi sendromu sunulmaktadır.

Anahtar Sözcükler: Chediak-Higashi sendromu, Albinizm

\section{INTRODUCTION}

Chediak Higashi syndrome (CHS) is a rare autosomal recessive multi-organ disorder of humans, cattle, mink, mouse and other mammalian species which possibly results from defective regulation of fusion of primary lysosomal granules with delayed microbial killing $(1,2)$. It is characterized clinically by recurrent bacterial infections (usually respiratory tract, skin and mucus membranes), partial oculocutaneous albinism, nystagmus, photophobia and rarely peripheral neuropathy, mental retardation and hyperpigmentation of exposed areas. The diagnostic hallmark of this syndrome is the presence of abnormal giant granules in neutrophils which are peroxidase positive $(3,4)$.

Around 200 cases of this syndrome have been reported since it was first recognized. However, there are only a few case reports from India (3,5-9). We report two cases of CHS in two siblings who presented with characteristically unusual feature of hyperpigmentation of the face and extensor aspect of the extremities.

Received : 21.03 .2010

Accepted : 18.08 .2010

\section{CASE PRESENTATION}

A 2-year-old boy presented with fever, cough and abdominal distention for the last fifteen days. There was a prior history of repeated attacks of fever and upper respiratory infections since the age of 8 months. He was the second child from a consanguineous marriage. His developmental milestones were delayed.

On examination, the child was febrile, poorly built and undernourished with dark grey hair showing a silvery tint. There was diffuse hyperpigmentation of the sun-exposed areas like the face and extensor aspects of the upper and lower extremities with speckled hypopigmented macules over the neck, lower abdomen, thighs and back. The child was anemic with cervical and axillary lymphadenopathy. Respiratory system examination revealed tachypnea with bilateral coarse crepitations. There was hepatomegaly $(5 \mathrm{~cm}$ below the costal margin) and splenomegaly $(8 \mathrm{~cm}$ below the costal margin). The cardiovascular and nervous systems were normal.

Correspondence: Mukta PUJANI

Department of Pathology, Lady Hardinge Medical College,

NEW DELHI, INDIA

E-mail: drmuktapujani@gmail.com Phone: +93 13850205 
The relevant hematological findings were hemoglobin 4.5 gm\%, total leucocyte count (TLC) $9500 / \mu$, platelet count $70000 / \mu \mathrm{l}$ and erythrocyte sedimentation rate (ESR) 45 $\mathrm{mm}$ in 1st hour. Differential leucocyte counts showed $80 \%$ lymphocytes, $18 \%$ neutrophils and $2 \%$ monocytes. The characteristic feature in the peripheral blood film was the presence of several abnormal giant granules in the neutrophils which were myeloperoxidase positive and single large azurophilic granules in most of the lymphocytes (Figure 1). Red blood cells were microcytic hypochromic with moderate anisocytosis. Bone marrow aspirate smears revealed normocellular particles with a myeloid to erythroid ratio of 3:1. The granulocytes and their precursors revealed the presence of similar giant granules which were myeloperoxidase and sudan black B positive (Figure 2).

Routine urine, biochemical parameters and CSF examination were normal. Blood cultures and urine cultures were negative. Serology for toxoplasma, rubella, cytomegalovirus, dengue and herpes were negative. Fine needle aspiration of cervical lymph nodes revealed features of reactive lymphadenitis. Chest $\mathrm{X}$ ray showed consolidation of bilateral lower zones. Abdominal ultrasound revealed hepatosplenomegaly with a normal echo pattern.

A diagnosis of CHS was established by the characteristic giant peroxidase-positive granules in granulocytes and their precursors in the blood and bone marrow. The peripheral blood films of his parents and sibling were examined and showed similar giant granules in the neutrophils of the older brother. The lymphocytes also showed single large azurophilic granules. Retrospectively, the parents gave a history of one or two episodes of fever and upper respiratory infection in the older brother. On examination of the sibling, there were similar findings such as a silvery tint to his hair and hyperpigmentation of face and extremities. However, there was no lymphadenopathy or hepatosplenomegaly. Hematological parameters revealed hemoglobin $9.0 \mathrm{gm} \%$, TLC $10500 / \mu \mathrm{l}$ and platelet count $170000 / \mu \mathrm{l}$. The peripheral smears of the parents were unremarkable. The children were given symptomatic treatment in the form of antibiotics and packed cell transfusion for anemia.

\section{DISCUSSION}

CHS was first described by Bequez Cesar in 1943. Further reports by Chediak in 1952 and Higashi in 1954 which emphasized the hematological features led Sato to associate their names with the anomaly $(1,9)$.

CHS is a rare autosomal recessive disorder resulting from defects in granule morphogenesis and is characterized by partial oculocutaneous albinism, repeated pyogenic

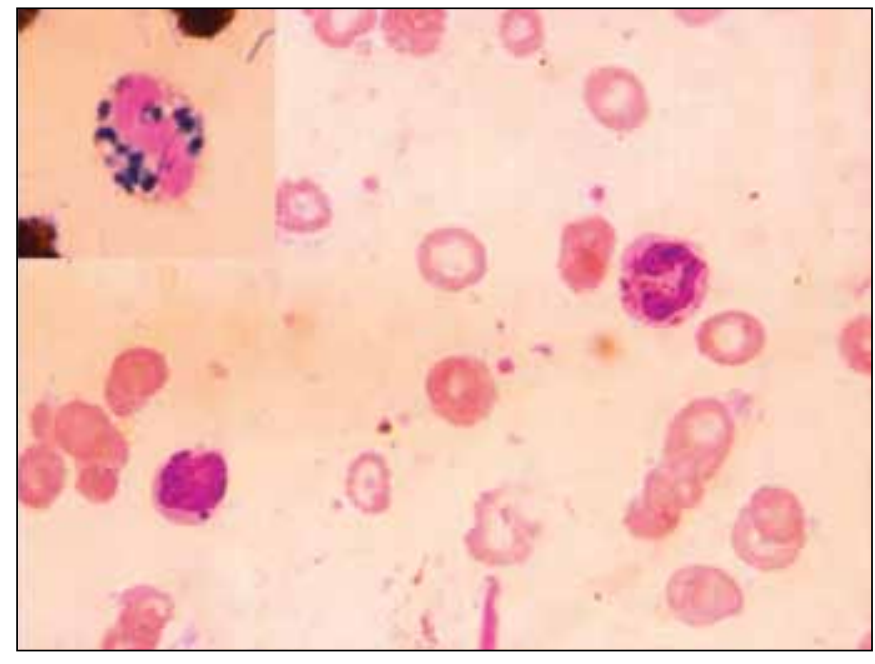

Figure 1: A neutrophil showing giant granules and a lymphocyte with single large azurophilic granule (Wright's stain, 1000x); inset-neutrophil showing peroxidase positive granules (Myeloperoxidase, $\mathrm{x} 1000$ ).

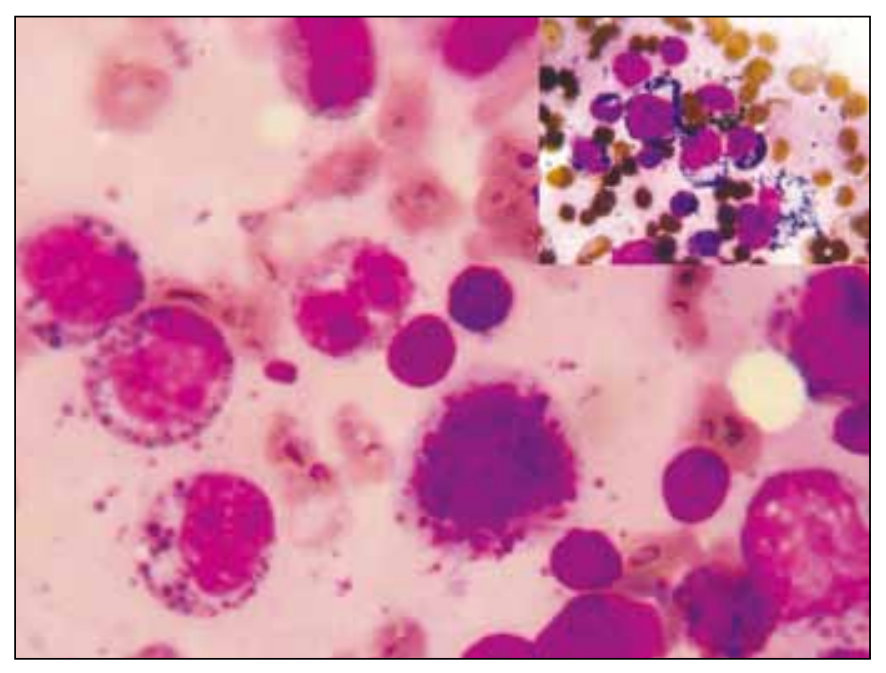

Figure 2: Bone marrow aspirate smear showing myeloid precursors with abnormal granules (Wright's stain, 1000x) inset- myeloid precursors showing peroxidase positive granules (Myeloperoxidase, x1000).

infections, peripheral neuropathy and the pathognomonic abnormal giant granules in the neutrophils. Giant granules may also be present in lymphocytes, monocytes, platelets, melanocytes, renal tubular cells, pneumocytes, gastric cells, hepatocytes, neuronal cells and fibroblasts. In melanocytes, there are giant melanosomes which prevent the even distribution of melanin and result in hypopigmentation of the hair, skin, iris and ocular fundus $(1,2,10)$.

The increased susceptibility to recurrent infections can be attributed to defects in $T$ cell cytotoxicity and natural killer cell function, and defects in chemotaxis and bactericidal 
activity of granulocytes. About $50-85 \%$ of the patients with CHS enter into an accelerated phase manifested by fever, jaundice, hepatosplenomegaly, lymphadenopathy and widespread lymphohistiocytic infiltration of various organs with hemophagocytosis leading to pancytopenia and bleeding disorder secondary to low platelets and fibrinogen levels. The accelerated phase may occur shortly after birth or several years later, which may be fatal if untreated $(2,11)$.

Uyama et al suggested two distinct clinical presentations of this syndrome: 1) the more commonly recognized childhood form with a typical history of recurrent infections leading to early death or an accelerated phase and 2) the rare adult type in which neurological defects resembling parkinsonism, dementia or spinocerebellar degeneration and peripheral neuropathy dominate with a lack of increased susceptibility to infections (12).

The defect in granule morphogenesis in multiple tissues is due to mutations in the CHS-1 gene, encoding a lysosomal trafficking regulator protein. It is homologous to the beige locus on mouse Chromosome $13(1,9)$.

Differential diagnosis of CHS includes other genetic forms of oculocutaneous albinism like Griscelli syndrome and Hermansky Pudlak syndrome, but both these syndromes lack the characteristic giant granules in neutrophils which are the hallmark of CHS. Acute and chronic myeloid leukemia may show giant granules resembling those seen in CHS, also referred to as pseudo-Chediak Higashi anomaly (1).

Treatment options for CHS are limited and are mainly symptomatic, that is antibiotic therapy for infections, and blood product replacement for bleeding complications. In the accelerated phase, etoposide, steroids and intrathecal methotrexate have been tried (1).

Our cases were unusual because the children had hyperpigmentation of the sun exposed areas like face and extensor aspects of upper and lower extremities with speckled hypopigmented macules over the neck, lower abdomen, thighs and back instead of cutaneous hypopigmentation. Hyperpigmentation of skin in CHS is rare but has been reported (13). The lack of awareness of this unusual finding in CHS might lead to the consideration of other photosensitivity diseases with hyperpigmentation and thus delay in the diagnosis of this syndrome.

\section{REFERENCES}

1. Skubitz KM: Qualitative disorders of leucocytes. In Lee GR, Foerster J, Lukens J, Paraskevas F, Greer JP, Rodgers GM. (Eds): Wintrobe's Clinical Hematology. 12th ed., Philadelphia, Williams \& Wilkins, 2009, 1548-1564

2. Blume RS, Wolff SM: The Chediak-Higashi syndrome: studies in four patients and review of the literature. Medicine 1972, 51: 247-280

3. Yasha TS, Vani S, Vasanth A, Augustus M, Ramamohan Y, Das $S$, Shankar SK: Chediak-Higashi syndrome - A case report with ultrastructure and cytogenetic studies. Indian J Pathol Microbiol 1997, 40:75-79

4. Fukai K, Ishii M, Kadoya A, Chanoki M, Hamada T: ChediakHigashi syndrome: A report of a case and review of the Japanese literature. J Dermatol 1993, 20:231-237

5. Seth P, Bhargava M, Kalra V: Chediak-Higashi syndrome. Indian pediatr 1982, 19:950-952

6. Prakash C, Suvarna N, Rajalakshmi PC, Aravindan KP, Chandrasekharan KG: A case of Chediak-Higashi syndrome JAPI 1990, 38:505-507

7. Rao CR, Appajji L, Lalitha N, Bhargava MK: Chediak-Higashi syndrome. Indian J Pediatr 1989, 56:778-780

8. Usha HN, Prabhu PD, Sridevi $M$ et al: Chediak-Higashi syndrome. Indian Pediatr 1994, 31:1115-1119

9. Kumar P, Rao SK, Shashikala P, Chandrashekar HR, Banapurmath CR: Chediak-Higashi syndrome. Indian J Pediatr 2000, 67:595-597

10. Barak Y, Nir E: Chediak-Higashi syndrome. Am J Pediatr Hematol Oncol 1987, 42-55

11. Rubin CM, Burke BA, McKenna RW, McClain KL, White JG, Nesbit ME Jr, Filipovich AH: The accelerated phase of ChediakHigashi syndrome. Cancer 1985, 56:524-530

12. Uyama E, Hirano T, Ito K, Nakashima H, Sugimoto M, Naito M, Uchino M, Ando M: Adult Chediak-Higashi syndrome presenting as parkinsonism and dementia. Acta Neurol Scand 1994, 89:173-183

13. Al-Khenaizan S: Hyperpigmentation in Chediak Higashi Syndrome. J Am Acad Dermatol 2003, 49:244-246 